\title{
ERRATUM
}

Murat Sertel · Arkadii Slinko

\section{Ranking committees, income streams or multisets}

Received: 16 November 2004 / Accepted: 6 October 2005 / Published online: 9 February 2006 (C) Springer-Verlag 2006

\section{Economic Theory (2005) DOI 10.1007/s00199-005-0054-6}

Due to an unfortunate error, the name of the second author as well as the affiliation of the first author were deleted from the original version of the HTML file when the proof corrections were carried out.

The online version of the original article can be found at http://dx.doi.org/10.1007/s00199-0050054-6

Murat Sertel was deceased (1942-2003)

M. Sertel

Department of Economics, Koç University,

Istanbul, Turkey

A. Slinko $(\varangle)$

Department of Mathematics, University of Auckland,

Auckland, New Zealand

E-mail: a.slinko@ auckland.ac.nz 